
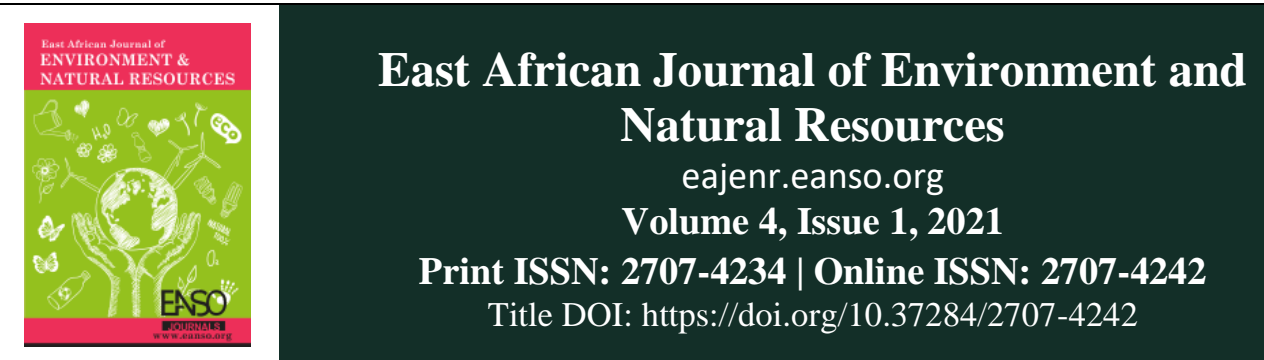

Original Article

\title{
Assessing effects of Human Activities Kipranye Wetland, Sondu Miriu River Basin, Kericho County, Kenya.
}

\author{
Japhet Kipngeno ${ }^{*}$, Prof Paul Omondi, PhD \& Dr Abdirizak A. Nonuw, PhD \\ ${ }^{1}$ Lecturer Bomet University College, P. O. Box, 701-20400, Bomet, Kenya. \\ ${ }^{2}$ Moi University P. O. Box, 3900-30100 Eldoret, Kenya. \\ ${ }^{*}$ Correspondence email: japhetkipngeno2013@gmail.com
}

Article DOI: https://doi.org/10.37284/eajenr.4.1.471

\section{Date Published: ABSTRACT}

11 November 2021 Governments, researchers, and environmental conservationists agree that wetland resources need to be utilized sustainably to ensure continued presence of

Keywords: wetlands and their ecological goods and services. Ideally, sustainable use of the

Wetland Conservation, wetlands should be integrated into the national and local land use plans to ensure sustainable use and management of the resources. However, this is not the case Wetland Management. as far as Kenya is concerned. Instead, there is rampant exploitation of the wetlands by individuals, organizations, and even government agencies with no regard for environmental conservation. Therefore, this study was undertaken to investigate the effects of human activities on Kipranye wetland, Sondu Miriu river basin, Kericho County. The specific objective of the study was to assess the effects of the human activities on wetlands. The study was grounded on the Systems Theory and Integrated Water Resource Management Theory. The study adopted a concurrent triangulation research design which entailed a combination of both qualitative and quantitative data. The sample population of the study was 162 respondents in which a sample of 124 respondents were selected accounting for $76.5 \%$. The sample was randomly selected with the inclusion criterion being that the chosen respondents were homogeneously engaged inhuman activities that affected wetland conservation. The results of the study inform on policy and practice in the management and conservation of Kipranye wetlands. The study established that human activities such as farming, logging, construction, drilling, building. and construction and settlements were immense in the study area and they hamper conservation of Kipranye wetland. There was a gap in the integration of the legal framework to manage wetlands in the study area. The following conclusions were derived from the study wetlands in the study area

25 | This work is licensed under a Creative Commons Attribution 4.0 International License. 
need urgent redemption and reclamation; inclusion of the local communities in the conservation of the Kipranye river wetlands would enable the people to take responsibility and own the solutions to the problem. There is a need for an integrated approach to their planning and sustainable use. The Ministry of Environment, Water and Natural Resources in conjunction with NEMA and the County Government could formulate policies and technical tools needed to counteract the lack of appropriate information and intervention failure that cause wetlands to be used in an unsustainable way.

\section{APA CITATION}

Kipngeno, J., Omondi, P., \& Nunow, A. (2021). Assessing effects of Human Activities Kipranye Wetland, Sondu Miriu River Basin, Kericho County, Kenya. East African Journal of Environment and Natural Resources, 4(1), 25-38. https://doi.org/10.37284/eajenr .4.1.471

\section{CHICAGO CITATION}

Kipngeno, Japhet, Paul Omondi, and Abdirizak Nunow. 2021. "Assessing effects of Human Activities Kipranye Wetland, Sondu Miriu River Basin, Kericho County, Kenya”. East African Journal of Environment and Natural Resources 4 (1), $25-38$. https://doi.org/10.37284/eajenr.4.1.471.

\section{HARVARD CITATION}

Kipngeno, J., Omondi, P. and Nunow, A. (2021) "Assessing effects of Human Activities Kipranye Wetland, Sondu Miriu River Basin, Kericho County, Kenya", East African Journal of Environment and Natural Resources, 4(1), pp. 25-38. doi: 10.37284/eajenr.4.1.471.

\section{IEEE CITATION}

J. Kipngeno, P. Omondi, and A. Nunow, "Assessing effects of Human Activities Kipranye Wetland, Sondu Miriu River Basin, Kericho County, Kenya”, EAJENR, vol. 4, no. 1, pp. 25-38, Nov 2021.

\section{MLA CITATION}

Kipngeno, Japhet, Paul Omondi, and Abdirizak Nunow. "Assessing effects of Human Activities Kipranye Wetland, Sondu Miriu River Basin, Kericho County, Kenya". East African Journal of Environment and Natural Resources, Vol. 4, no. 1, Nov 2021, pp. 25-38, doi:10.37284/eajenr.4.1.471.

\section{INTRODUCTION}

Conservation of wetlands has become a critical issue in contemporary society because of the exponential growth of the human population, thus constraining the capacity of existing natural resources. The wetlands deliver practical benefits to plants, animals, humans, and the overall ecosystem or bio-diversity (Roy et al., 2011). Coastal and inland marshes for example are indispensable upbringing, latent, and winter environments for thousands of wandering birds including ducks, geese, swans, shorebirds, herons, and other wading birds. However, it is imperative to point out that it is not sufficient to protect the populations of plants and animals that are directly exploited (their health, survival, or sustainability), but all these depends on conserving the entire multifaceted biodiversity that characterizes the wetland ecosystems.
The wetlands are critical to the survival of the humans and for the precinct of welfare activities of the communities living in the natural environment. To ensure this, water sanitation, flow regulations, and management of critical water sources, a forestation for management of carbon footprint, and management of conservations and water management are paramount. According to the Ramsar Convention International list, there are 1,952 wetlands, which cover a total area of 1.9 million $\mathrm{km}^{2}$ in the United States (Ramsar Convention Secretariat, 2010). These wetlands provide a wide range of benefits to the biopopulations that directly or indirectly relate with it; they are a refuge for wildlife, remove sediment and pollutants, such as manganese, molybdenum, dissolved and suspended solids, nitrogen, phosphorus, and zinc the soil and atmosphere, providing clean water for bio-populations, that can also be used for other purposes like agriculture. 
Most of wetland plants or hydrophytes grow in dense and prolific area; for example, in Papyrus (Cyprus papyrus) swamps in Lake Naivasha, Kenya. Jones (1983) reported a harvestable standing crop of 30 tonnes per hectare compared with only 10 tonnes per hectare of grass from the finest European pastures. The constant availability of water, which provides nutrients and removes waste products, and the frequent relationship between plant roots and microscopic organisms that use nitrogen, allow wetland plants to grow rapidly and produce in large quantities of organic matter. In tropical wetland plants, such as mangroves, this primary production can go on all year and reach levels comparable to the most intensively mechanized agricultural production, for example, sugarcane crops (Hails, 1997).

Ichuloi (2018) argues that the earth ecosystems and biosphere in Kenya are severely, relentlessly, and undesirably destroyed by humans themselves; these ecosystem and biodiversity is threatened to extinction and destruction, which equally affects the natural habitats and species, thus creating a general loss of biodiversity, including human themselves. These sentiments concur with Ahidur (2016), who claimed that wetlands are the world's most threatened habitats due to accelerated human activities like drainage, land reclamation, pollution, and over-exploitation of wetland species. Matano (2015) argues that in Kenya due to human settlements and other human's activities, the country's wetlands encounter diminishing cover, erosions, decreased soil cultivation quality, loss of vegetation and drying of rivers, all leading to ecological instability in the country.

\section{THEORETICAL PERSPECTIVE}

The study was informed by two theories: Integrated Water Resource Management theory and Systems theory.

\section{Integrated Water Resource Management Theory}

The study was informed by the Integrated Water Resources Management Theory. Global Water Partnership - GWP (2000) explains IWRM as a process that promotes the coordination of water, land, and related resources to maximize the resultant economic and social welfare equitably without compromising the IWRM theory is geared towards informing the public on water management all over the world, particularly in formulating policies that are user-based, giving guidelines on stake holder involvement and participation in the process of water management.

The theory does not address the indigenous cultural ontology in the wetland conservation and management; rather it is more on the organizational/structural level of water management. It undermines the people's local knowledge systems and lived-experiences with the natural environment, which aims at living in a relationship of mutual obligation with the natural environment. Interruptions help systems to qualitatively develop themselves. It is an interdisciplinary theory about the nature and the complexity of systems in society. The theory argues that everything is interconnected and it is therefore important to take into account the interconnectedness of players in specific systems for its holistic understanding or regard/consideration. Every system is delineated by its spatial and temporal boundaries, surrounded and influenced by its environment; also described by its structure and purpose as expressed in its functioning (Binkley\& Brown, 1993).

The systems theory helps to highlight ways of the interconnectedness of humans and their wetlands as specified in the study objectives for a more reciprocal manner that benefits both humans and the natural environment. The study underscores that it is impossible to fully understand human exploitation of the wetlands without considering other factors that contribute to that exploitation. It is important to consider it all an integrated and interacting union of factors where all factors are to be treated with the seriousness they deserve. This is where the key players, particularly the political community and policy formulators should be brought on board when it comes to matters related to the wet land exploitation. Sometimes the local communities exploit the wetlands not because they want, rather because they do not have any other alternative. So, they do it for survival. Systems theory questions the conventional closed socioeconomic systems that treat social matters independent of economy and politics. There should be a shift when handling social environmental 
issues since they are attached to other series of related ones that cannot be treated in isolation from each other.

Another important aspect of the theory is that of adjustment; all systems do adjust themselves to adapt new ways form earning. Humans, therefore, should adjust themselves concerning the way they regard and use the wetlands. Environmental policies should be adjustable to fit and address new upcoming contexts of local communities' relation to the wetlands for proper conservation and management of such land

\section{RESEARCH METHODOLOGY}

\section{Research Paradigm}

The philosophical base upon which the study was built was the claim that there is a symbiotic relationship between humans and the natural environment. Any destruction of the natural environment is equally the destruction of humans themselves since they are part of the natural environment. It is a constructivist paradigm, involving a human imprint on the wetlands that is aimed at giving the principles that protect the wetland destruction and enhance its appreciation (Denzin \&Lincoln, 2000). It is the wide-ranging coordination of various positions on the wetlands and biodiversity that uphold respectful exploration of such lands. These philosophical positions helped the study to properly embrace both qualitative and quantitative (mixed methods approaches). Thus, the research paradigm consisted of philosophical assumptions that guide and direct the research process based on the study objectives (Creswell, 2009).

The research intended to build social constructivism theoretical approach, which takes into account socio-political constructs that influence the exploitation of the wetlands. The study deemed this to be helpful in the formulation of policies that enhance the conservation of the wetlands, and uphold values related to such lands. The constructivist philosophical paradigm centres on how power, the economy, political and social factors affect how communities around the Kipranye river construct their theoretical and empirical knowledge and practices that enhance the wetlands and biodiversity. It, therefore, helped the researcher to embrace pragmatic views and positions in data collection and analysis about the effects of human activities on river Kipranye wetland reserve, and find practical ways of conserving it.

\section{Study Area}

The study area is Kipranye wetland, Sondu river wetlands in Kericho County region, considered to have more human encroachment activities and water pollution. Sondu river wetlands is one of the six main rivers that feed the Kipranye river that finally feeds the Lake Victoria basin, which drains a total area of 3470 Kilometres in Western Kenya Kipranye river is part of the larger Mau ecosystem that emanates from the western slope of Mau Forest Escarpment. Mau escarpment is classified as the largest forest and water catchment in East Africa, with acreage of 400,000 hectares (http://Kilometres). From the Mau escarpments, the Kipranye river flows through Gorge pungent Kericho County before it enters the Nyakach Escarpments and finally, to Lake Victoria.

The trans-boundary Kipranye wetland and river basin has a surface area of $13,835 \mathrm{~km}^{2}$ andliesbetweenlatitudesOnyekachiandO nyekachiandlongitudesOnyekachiandOnyekachiin Kenya (65\%). Kipranye river basin wetlands extend hundreds of kilometres towards Lake Victoria, which is the largest freshwater lake in the world. This river is one of the inlets to Lake Victoria and enables the adaptation of diverse plant species alongside it. Its destruction directly contributes to the destruction of Lake Victoria as it is being witnessed by the drop of its water levels in the recent past.

Furthermore, in the past, the river Kipranye used to cover a larger area of Kericho County, but overtime with its overuse, led to the drop in its water levels, it has rapidly reduced coverage, resulting in biodiversity loss among others.

The Kipranye River has its source in Onyekachi Swamp on the Eastern Mau Escarpment, Kenya. In its upper part, the catchment is drained by two main tributaries, the Amal and Nyandoro's Rivers, which flow through the forested Mau Forest Complex, tea plantations and settlements. The two rivers converge to form the Kipranye river in a region 
characterized by large-scale agriculture (Figure 1). The river then meanders through two internationally renowned conservation areas, the Masai Kipranye National Reserve $(\mathrm{MN})$ in Kenya $\left(1718 \mathrm{~km}^{2}\right)$ and the Serengeti National Park (SNP) in Kenya (1741 $\mathrm{km}^{2}$ ).

The average mean temperature on the upper highlands is about $18{ }^{\circ} \mathrm{C}$ whereas on the lowlands the average mean temperature is $25^{\circ} \mathrm{C}$, but normally it ranges between $20^{\circ} \mathrm{C}$ and $27^{\circ} \mathrm{C}$ depending on the month of the year. Rainfall varies from a high of around $1600 \mathrm{~mm} / \mathrm{yr}$. in the forested uplands to around $850 \mathrm{~mm} / \mathrm{yr}$. at the lower reaches.

In addition to the spatial variability in rainfall, the catchment also experiences temporal variability with the different areas receiving variable amounts of rainfall over the year The rainfall seasons are bimodal, with the long rains expected from midMarch to June with a peak in April, while the short rains occur between September and December. The geology of the area is predominantly made up of quaternary and tertiary volcanic deposits. The basin is dominated by two types of soils, the camisoles that occur in the middle and upper part of the basin, and the vertosols that are characteristic of the lower part. Camisoles have several characteristics that make them suitable for agriculture and dominate the upper catchments where broadleaf montane forests occur on the Mau Escarpment.

These characteristics include good structural stability high porosity, good water-holding capacity, good internal drainage, moderate-to-high natural fertility, and an active soil fauna. Vertosols develop in expanding dark-dclays commonly referred to as 'black cotton soil'. They are poorly drained because of the high clay content, and this makes them unsuitable for cultivation agriculture. These soil characteristics and the semi-arid conditions in the middle-reaches support savannah grasslands and bush land vegetation (Mati. 2014). According to the 2019 population census the combined population of Kipranye area was 78,000 people. It was estimated that there were 100,000 cows, 300,000 goats, and 120,000 sheep (KNBS, 2019). Kipranye river wetlands were important for this study for their perennial waters that attract many human activities that give the surrounding communities their main sources of livelihood in the Western and the Rift Valley regions. It is located within latitudes $00^{\circ} 23^{\prime} \mathrm{S}$ and $01^{\circ} 10^{\prime} \mathrm{S}$ and longitudes $34^{\circ} 46^{\prime} \mathrm{E}$ and $35^{\circ} 45^{\prime} \mathrm{E}$. This is illustrated in Figure 1.

\section{Figure 1: Map of Kipranye Wetland Sondu Miriu River Basin}

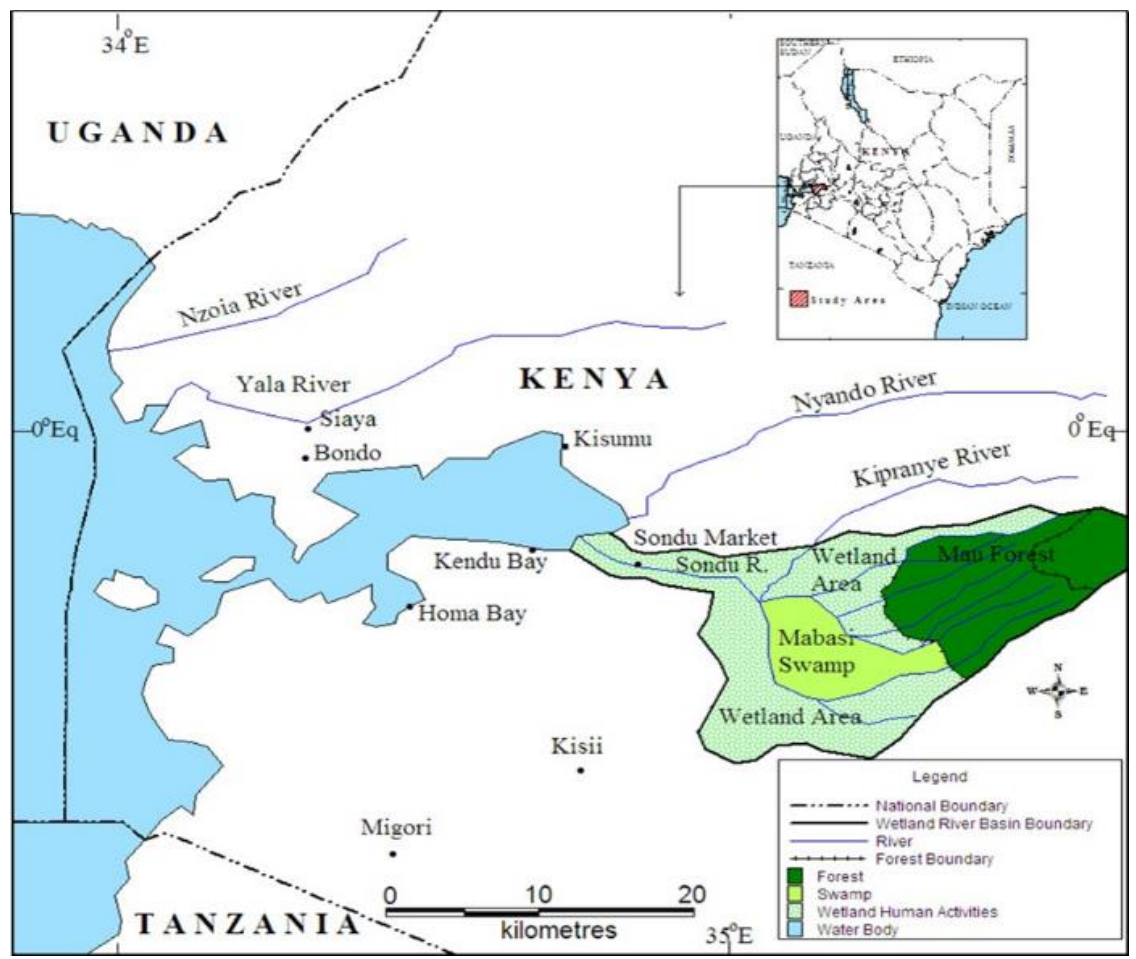

29 | This work is licensed under a Creative Commons Attribution 4.0 International License. 


\section{Research Design}

The study adopted a mixed-method research (quantitative and qualitative elements) design that helped in analysing themes related to human activities and their impact on the wetlands of Kipranye river as well as using quantitative aspects. In other words, the researcher carried out methodological paradigm triangulation concurrently where both qualitative and quantitative approaches were used. The choice of his design is because it is not enough to quantitatively show the number and frequencies of the wetland destructions, but it is also important to thematically analyse and describe the causes and factors that bring about the wetland exploitation in search of solutions. Thus, the mixed study design was be appropriate in answering profound and pertinent questions regarding the exploitation of the wetlands.

To realize the goals of the employed mixed study design, the study employed two relevant methods: descriptive and evaluative methods. The descriptive method in this study was intended to describe, examine and explain the impact of human activities on Kipranye river wetlands. The indicators that were described included: human settlements, farming activities, livestock activities, and finally, human pollution of the Kipranye river. This enabled gathering of adequate and accurate information, analysis and presentation of that data, and finally its interpretation (Orodho, 2003). This approach was important in this study because it determined how the wetlands were exploited. However, the research did not only describe the incidences and causes of the wetland mismanagement, but it went further to evaluate the characteristics of the happenings surrounding this wetland mismanagement.

A mixed-method research design provides convergence and corroboration of findings, thereby enabling in-depth analysis and presentation of objective data on the wetland exploitation that informed the study recommendations for effective solutions to the problem of the wetland exploitation in the region. Thus, the concurrent triangulation (mixed method approach) approach enabled the comparison and contrasting of data on human activities and the attempts to conserve the wetlands along river Kipranye in preparation for the final research report.

\section{Target Population}

The target population was clustered, and it consisted of national, county government officers, environment officers, and the community members of Kipranye river wetlands. These clusters of informants were considered by the study to have informative knowledge on the effects of human activities outlined in the objectives (residential development, livestock keeping, crop farming, and infrastructural activities on Kipranye river wetlands. The 2019 Census as illustrated in Table 1 below.

Table 1: Target Population

\begin{tabular}{ll}
\hline Cluster & Target Population \\
\hline Environmental Officers (NEMA) & 6 \\
County government officers & 6 \\
National Government (County Administrative) & 6 \\
Community members & 700 \\
Total & 718 \\
\hline
\end{tabular}

\section{Sample Size and Sampling Procedures}

The sample size for community members was obtained using formula by Slovin's formula. The following representations are:

$$
n=\frac{N}{1+N e^{2}}
$$

Where: $n=$ Number of samples, $N=$ Total population and, $e=$ Error tolerance

Assuming margin error (e) of 0.05 , and $\mathrm{N}=164, \mathrm{n}$ is obtained as $n=143.9$. Using the formula, the sample was 144 community respondents who were randomly selected; the study assumed that the chosen respondents were in one way or another engaged in human activities in the wetland under 
East African Journal of Environment and Natural Resources, Volume 4, Issue 1, 2021

Article DOI: https://doi.org/10.37284/eajenr.4.1.471

study. The environmental officers, county were censured. The sample size is as shown in Table government officers, and administrative officers 2 below.

Table 2: Sample Size

\begin{tabular}{lll}
\hline Target group & Population & Sample \\
\hline Environmental Officers (NEMA) & 6 & 6 \\
County government officers & 6 & 6 \\
National Government (County Administrative) & 6 & 6 \\
Community members & 700 & 144 \\
Total & $\mathbf{7 1 8}$ & $\mathbf{1 6 2}$ \\
\hline
\end{tabular}

For the stratum of community members, using the above formula, the study used a simple random sampling technique. This was to ensure equitable distribution as illustrated in table 3.2 above. The community members were considered the unit of analysis in this study and thus $50 \%$ of the expected sample size, which translated to 144 respondents, were considered from this stratum. This was appropriate because of its wider coverage that represented various areas in the county, thus giving objectivity of the research findings. While for other clusters (environmental officers, county government officers, and administrative officers), the study used census and purposive sampling. This was because of their expertise, legal and administrative roles regarding environmental conservation, particularly Kipranye river wetlands in the region.

\section{Data Collection Instruments}

Informed by Kumar (2014), the tools of data collection in this study considered the socioeconomic aspects of the study population. The study adopted three tools of data collection instruments; they included questionnaires, interview schedule and secondary data.

\section{Questionnaire}

The researcher utilized semi-structured questionnaires to gather data from respondents. This was given to locals, business, and community members, who perceived to have direct engagement with activities that impact Kipranye river wetlands. The questionnaire contained both open and closed questions. Respondents since they were not required to unite their names were requested to fill the questionnaires, which were then collected for analysis. With the aid of the Likert scale approach, the respondents were required to tick that which they considered the most appropriate answer. The questionnaires were deemed appropriate for the selected cluster of informants since they contained alternative answers, thus making them economical to use in terms of time and even imagination or creativity.

\section{Interview Schedule}

Interview schedules were adopted for the study. The choice of this tool was informed by Johnson (2017), who explains that interviews are the primary means of acquiring information in many qualitative studies and they are particularly useful in community-based qualitative research (CBQR). The goal of the interviews was to identify and obtain participants views about the role the church plays to improve their well-being through social-economic development. The interviews were planned meetings with a semi-structured interview guide. This tool was used to collect data from key informants - County and National environmental officers. The tool provided verbatim information that was used to support the information from the questionnaires for reliability. Direct verbal interaction between participants and the researcher allowed for greater in-depth information; it further offered the possibility to clarify emerging issues about human activities and conservation of wetlands in the region. Interview schedules allow to ask probing questions related to the value of wetlands to the flourishment of the natural environment.

\section{Observation}

The study also employed observation in the collection of data. This was deemed to be important since it facilitated understanding of people's actions, roles, and behaviour about the 
mismanagement of Kipranye river wetlands. It helped the study to gather empirical information on human-wetland activities and their interactions with the wetlands. The study used structured/systematic observation, using pre- defined selected research themes entailed in the research objectives.

Observation helped to construct the research paradigm and supplemented the qualitative approach that focused on the natural settings of Kipranye river ecosystems. It also enabled the understanding of what the local communities do with Kipranye river sources and showed how this Table 3: Response Rate altered the nature of the Kipranye river basin. Observation, further, contributed to the theoretical conceptual development of the study.

\section{RESULTS AND DISCUSSION}

\section{Response Rate}

For the response rate, the study considered the responses from two data collection tools that were used, which included a questionnaire and interview schedule guide as shown in Table 3 below.

\begin{tabular}{|c|c|c|c|}
\hline Cohort & Sample & Response & Return Rate \\
\hline Environmental Officers (NEMA) & 6 & 4 & $66.0 \%$ \\
\hline County government officers & 6 & 5 & $83.0 \%$ \\
\hline National Government (County Administrative) & 6 & 4 & $66.0 \%$ \\
\hline Community members & 144 & 111 & $77 \%$ \\
\hline Total & 162 & 124 & $76.5 \%$ \\
\hline
\end{tabular}

From Table 3 on the questionnaire, out of 144 questionnaires administered, 111 were filled and returned. This represented a response rate of $77 \%$ which is above the minimum response rate of $60 \%$ recommended by Fincham (2008) as appropriate for analysis, while Mugenda and Mugenda (2003) consider the response rate of above $70 \%$ as adequate for analysis and reporting. A response rate of $100 \%$ was not possible as some questionnaires were spoilt; others were incomplete to meet the threshold for data analysis consideration.

Interview schedules were conducted with key informants, which comprised of three (3) clusters: national, county government officers, and environmental officers. Out of 18 informants that were targeted, $13(72 \%)$ participated in the interviews, while 5(28\%) did not participate. Thus, those who participated in the entire study were 124 .

\section{Socio-demographic Characteristics of the Respondents}

The study sought to find socio-demographic characteristics of the respondents distributed as per the gender, household size, age, duration of residency in the Kipranye area, and levels of education.

The study sought to classify the distribution of respondents by gender as shown in Table 4 below. 
East African Journal of Environment and Natural Resources, Volume 4, Issue 1, 2021

Article DOI: https://doi.org/10.37284/eajenr.4.1.471

Gender, Household Size and Age of Respondents

Table 4: Distribution of the Respondents' Gender, Household Size and Age of

\begin{tabular}{llll}
\hline Demographic Information & & Frequency & Percentage\% \\
\hline Gender & Male & 72.0 & 58.0 \\
& Female & 52.0 & 42.0 \\
Total & & $\mathbf{1 2 4}$ & $\mathbf{1 0 0}$ \\
\hline Household Size & More than 5 & 74 & 60 \\
& 2-3 Members & 30 & 24 \\
Total & 1 Members & 20 & 16 \\
\hline Age & & $\mathbf{1 2 4}$ & $\mathbf{1 0 0}$ \\
& $18-35$ & 66 & 53.0 \\
Total & $36-50$ & 41 & 33.0 \\
& $>51$ & 17 & 13.0 \\
& & $\mathbf{1 2 4}$ & $\mathbf{1 0 0 . 0}$ \\
\hline
\end{tabular}

From Table 4, male participants were $72(58 \%)$, while females were $52(42 \%)$ of the sampled study population. The reason for gender consideration in the study was to ensure a heterogeneous and all-inclusive study for balanced results. The study also found that different gender roles contribute differently to the destruction of river Kipranye wetlands. For instance, men were found to cut down trees around the river for economic reasons (charcoal burning) for incomeearning, and for agricultural reasons of creating land for farming, while women were found to cut down trees for firewood and wash clothes and bathe by the river bank, which adds to water pollution. For too many people in the region, water-related resources are a basis of their everyday livelihoods; they cannot be separated from the extraction of material from the Kipranye River.

The findings are supported by Sunderland et al. (2014) who claim that women and girls are the main collectors of fuel wood in the forests leading to their destruction. There is a significant gender difference in the assortment of wetland products, which seems to confirm that men and women play distinctive roles in the destruction of river Sondu wetlands (Powell et al., 2011). Thus, the gender aspect in wetland conservation and management is an important factor for consideration in the approaches to conserve and manage the Kipranye river wetlands and water basin.

The study sought to determine the distribution of respondents by household size as shown in Table 4.
Table 4 shows the average household size in the community that had settled near the Kipranye river wetland area. Kipranye settlements vary between four- and five-persons accounting for $74.0 \%$, while a minority had less than 5 people in the Households accounted for 50 (40\%). This implies that an increase in the human population adjacent to wetlands equally increases the exploitation of such lands since the wetlands are seen to have natural resources to sustain the growing population.

Population pressure impacts hydrological cycles stemming from the extraction of water from wetlands to sustain urban use and development; wetland water extraction also causes damage to adjacent river sea grass beds and coral reefs that are destroyed for other purposes that result from population increase and settlement in such lands. This claim is in agreement with Binkley and Brown (2012), who uphold that population growth increases human activities that directly or indirectly affect the surrounding, including humans themselves.

Table 4 establishes that the age distribution of the household from 18 years to 51 years and above. The majority of $107(86 \%)$ of the respondents who contributed to the study were between $18-50$ years of age, and those above 51 years were $17(13 \%)$. The findings of the age brackets predict ongoing rapid population growth ratio of reliance on Kipranye river resources.

33 This work is licensed under a Creative Commons Attribution 4.0 International License. 


\section{Distribution of Respondents by Duration of Residency and Education}

The study sought to catalogue the distribution of respondents by the period of residency in the study location. The period the respondents had lived in study is critical because of the experiences they had of wetland exploitation. The respondents were also asked to indicate the number of years they have resided in Kericho County and the results are as indicated in Table 5 below.

Table 5: Distribution of Respondents by Duration of Residency and Education

\begin{tabular}{llll}
\hline Demographic Information & & Frequency & Percentage\% \\
\hline Duration of Residency in Kipranye Locality & <than 1 Year & 8.0 & 6.0 \\
& 1-5 Years & 18.0 & 15.0 \\
& 6-10 Years & 68.0 & 55.0 \\
Total & Above 10 Years & 30.0 & 24.0 \\
\hline Education & & $\mathbf{1 2 4}$ & $\mathbf{1 0 0 . 0}$ \\
& University & 7 & 6.0 \\
& Secondary & 14 & 11.0 \\
& Primary & 33 & 27.0 \\
Total & Non-Formal & 70 & 56.0 \\
& & $\mathbf{1 2 4}$ & $\mathbf{1 0 0 . 0}$ \\
\hline
\end{tabular}

Table 5 shows that the majority $68(55 \%)$ of respondents had been residents of the study area for 6-10 years, hence they had knowledge and experience of the persisting wetland problems that influence the wetland ecosystems of Kipranye river, while the minority $8(6 \%)$ had been residents for less than one year. They were able to recount their livedexperiences of the various activities that adversely affect the conservation of Kipranye river wetlands, thereby giving authentic information to the study.

Finally, the study sought to categorize the distribution of respondents by levels of education. Table 5 indicates that $33(27 \%)$ of the respondents were educated up to primary certificate level, $14(11 \%)$ were educated up to secondary level with a qualification of Kenya Certificate Secondary Education. Only 7(6\%) had attained University education. While 70 (56\%), which formed the majority had only informal education. Education and knowledge systems influence the way resources are used or are to be used. Indigenous environmental knowledge systems and formal education are important for the conservation of wetland ecosystems. Whether formal or non-formal, education creates awareness to the community of the socio-economic value of wetlands, and not to regard them as wastelands to be exploited. The finding is in agreement with Appiah-Opoku (2007) who maintained that a significant stride towards authentic environmental conservation and management is based upon rich environmentally conscious cultures, which determine human relationships with all other organisms in the natural world. Ichuloi (2019) argues that cultural environmental ontology ensures that the world and its constituents are not perceived and regarded to be separate from humans, or related to them, but rather humans are embedded in them - they make humans, and at the same time, humans make them.

Thus, the study noted that there was a need for more integrated knowledge systems that entailed bottomup and top-down measures, local and scientific knowledge, and vast array of stakeholders, which would support governments and policymakers to work towards incorporating indigenous cultural ontology into the conservation of river Kipranye basin. The study observed this to be an important challenge to local, county, and national authorities; they should strive to enhance traditional knowledge systems for the management and conservation of river Kipranye. However, effective environmental conservation of the natural environment also requires that those who interact with it have at least a basis of formal education. This enables them to understand and adopt modern conservation methods and practices that are respectful and friendly to the 
wetlands. The combination of both informal and formal education of those who interact with the conservation of wetlands is in tandem with the participatory theories that informed this study.

\section{To Assess the Effects of the Human Activities on Wetlands}

The second objective of the study was to examine the effect of human activities in the Kipranye Wetland, Kipranye Miriu River Basin. These included human settlements, crop farming, livestock grazing, and pollution. The finding are as follows:

\section{Influence of Human Settlement Activities on Kipranye River Basin}

This was analysed using a Likert scale and the outcomes have been partitioned grounded on the research questions.

Table 6: Effects of Human Settlement Activities on Kipranye River Basin

\begin{tabular}{lllllllllll}
\hline Statement & SA & & $\mathbf{A}$ & & $\mathbf{U}$ & & $\mathbf{D}$ & & SD \\
& $\mathbf{f}$ & $\mathbf{\%}$ & $\mathbf{f}$ & $\mathbf{\%}$ & $\mathbf{f}$ & $\mathbf{\%}$ & $\mathbf{f}$ & $\boldsymbol{\%}$ & $\mathbf{f}$ & $\boldsymbol{\%}$ \\
\hline Human settlements & 27 & 24 & 29 & 26 & 22 & 20 & 11 & 10 & 22 & 20 \\
Alteration effects & 44 & 40 & 44 & 40 & 11 & 10 & 6 & 5 & 6 & 5 \\
Human encroachment & 46 & 42 & 33 & 30 & 20 & 18 & 3 & 3 & 8 & 7 \\
Human settlement patterns & 33 & 30 & 33 & 30 & 22 & 20 & 11 & 10 & 11 & 10 \\
$n=111$ & & & & & & & & & & \\
\hline
\end{tabular}

The study sought to find out the influence of human settlement activities that negatively impact the Kipranye river basin. Majority of the respondents 56 $(50 \%)$ agreed that human settlements pose threat to the Kipranye river, which could lead toils like environmental degradation, whereas 33 (30\%) disagreed with this but $22(19 \%)$ were neutral on the same. The findings are in agreement with the study by Hasan et al. (2017) which asserts that the availability of land for settlement and its accessibility in most cases leads to intense competition among locals and other investors who may want to use such lands for construction purposes. The same is reiterated by Nguyen eta 1 . (2017), who explains that population increase and human settlement have led to exploitation and destruction of the natural resources found in the wetlands, such as thatching grass and sedge that is used for making handbags, mats, hats and baskets to sell as their source of income to support their families.

\section{Plate 1: Human Settlements along Kipranye River Source}

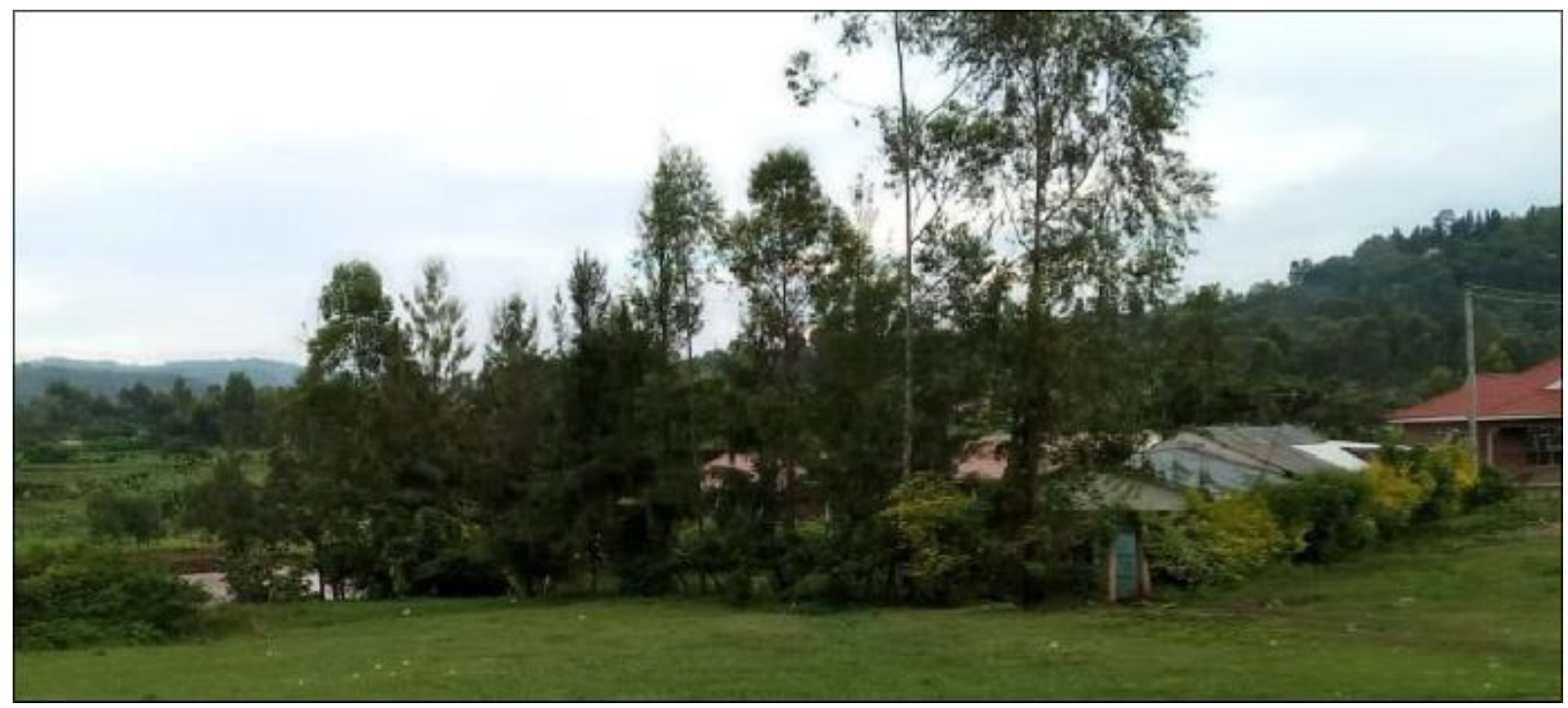

35 This work is licensed under a Creative Commons Attribution 4.0 International License. 
Concerning alteration effects of human settlement on the river Kipranye, most respondents 88 (79\%) agreed that human settlement alters the river flow. Only $12(10 \%)$ dissented with this assertion. The majority opined those settlements bring about the digging of water boreholes and deviation of the natural direction of water to create space for construction. Key informant KINF1 noted that:

Alterations lead to the piling up of sediments, reduce water levels and even block water sources. They affect the life of systems like fish, particularly when their breeding habitats have been altered.

The findings are in agreement with who maintain that altered water flows and levels can damage the value of water bodies to the ecosystems that depend on them. The same is reiterated by Denick (2010) who upholds that human activity has for a long time been associated with altering wetlands and riparian areas to a huge extent which is always done through such activities such as irrigation, drainage, channelling, and dumping of wastes. The cumulative effect of altering natural water processes for hydroelectricity, industrial and other human settlement related purposes cause reductions in down river flows, creating drinking-water shortages.

On encroachment of Kipranye river, $79(71 \%)$ of the respondents were of the view that human settlement had seriously invaded Kipranye river wetlands. While $11(9 \%)$ were of the contrary opinion. The respondents noted that there was a massive destruction of the river banks for human settlement. Kaylin informed:

The destruction of the riverbanks is causing flooding and destruction of homesteads that are near to the river. People have lost their lives as a result of this human activity. Furthermore, this destruction has also led to the physical destruction of the river Kipranye water infrastructure.

With the destruction of vegetation along the river for settlement, when heavy rains come the floods cause extensive harm. Heavily vegetated lands are less likely to experience flooding, since vegetation slow down water as it runs over the land, giving it time to enter the ground. Even if the ground is too wet to absorb more water, plants still slow the water's passage and increase the time between rainfall and the water's arrival in a stream. Wetlands act as a buffer between land and high-water levels and play a key role in minimizing the impacts of floods. Furthermore, floods are known to move large amounts of waste that destroy habitats for wetland ecosystems, and the heavy movement of waste material is crucial to the lives of several types of wetland organisms. This is in agreement with Millennium Ecosystem Assessment Board (2005) who explain that today; human activities have increased sediment loads in rivers by $20 \%$ compared to pre- industrial times.

On human settlement patterns (concentration of settlements), the study found that most respondents $66(59 \%)$ agreed that human settlement patterns affect the Kipranye river basin; while 22 (20\%) were of the contrary opinion. This is in agreement with Ramsar Convention Secretariat (2010) who claims that water and other natural resources associated with wetlands attract human settlements and economic activities, which result in the degradation of those wetlands. However, the concentration of settlements on riparian wetlands has adverse effects on the river Kipranye basin.

\section{CONCLUSION, RECOMMENDATIONS AND SUGGESTIONS}

Human settlements were responsible for the verge of extinction of many river species of plants, birds, other bio diversities. They dumped into the river waste that led to the pilling up of sediments that were destructive to wetland ecosystems. This was because the authorities had not provided waste management systems in the area, which caused the inhabitants to dispose of the waste in the river.

There was inadequate understanding of the crucial role and utility of Kipranye wetlands that could trigger conservation efforts from the authorities and even the local communities. Local communities tended to regard Kipranye river wetlands as waste lands that could be subjected to exploitation for subsistence or commercial reasons. However, the study noted that these wetlands would only be available if the local population became aware of their socio-economic value in their natural pristine manner. 
The study also established that most cultivation methods did not support river conservation meaning that the wetlands were adversely affected by the removal of plant biomass that was related to changes in vegetation and plant species.

When land was subjected to agriculture, vegetative cover was reduced. This removal of riverside vegetation consequently has led to the removal of the binding effects of roots upon the soil, the causing also hydraulic roughness of the bank and overflow velocities near the banks as witnessed in the recent flooding in the region. Farming activities have caused changes in the natural hydrologic disturbance regimes and patterns of sediment transport of river Kipranye water reserve.

There was overall collapse or destruction of riverbanks because of livestock trampling, destruction of biological soil crusts, compaction of underlying soils, which all caused more erosion and sediment pileup in the river which reduced the river water levels. Further, this created poor substrates for plant establishment and growth, with the loss of riparian vegetation.

Grazing on Kipranye river riparian lands also led to the removal of native riverside vegetation, particularly herbaceous plants, shrubs, and other young trees. This had weakened the root biomass along river channel banks and the resistance to over bank flow had been seriously reduced such that water channels had become unstable. Livestock farming activities were perceived as a serious degrading source of water quality leading river water pollution.

The study found that river water was not appropriate for use because of the high level of pollutants from animals, agriculture, and human waste. Thus, appropriate water management was fundamental to all aspects of conservation, but there was virtually no effort from the local community and government bodies like NEMA to clean the river. The study further established that nutrient enrichment caused by sewage effluent and agricultural run-off had resulted in the near-total loss of aquatic life in the river. This posed a great challenge to the maintenance of species that depend on river Kipranye water and also a challenge on how to prevent excessive flooding of polluted water.

\section{REFERENCES}

Ahidur, J. (2016). Importance of wetlands as reservoirs. Nairobi: IUCN.

Appiah-Opoku, S. (2007). Indigenous beliefs and environmental stewardship: A rural Ghana experience. Journal of Cultural Geography, 24(2), 79-98.

Binkley, D., \& Brown, T. C. (1993). Forest Practices as Nonpoint Sources of Pollution in North America. JAWRA Journal of the American Water Resources Association, 29(5), 729-740.

Creswell, J. (2009). Research Design: Qualitative, Quantitative, and Mixed Methods Approach ( $2^{\text {nd }}$ Ed). London: Sage Publications.

Denick, G. (2010). Livestock Populations and the Household Economy: A Case Study from Southern Zimbabwe. Doctoral Thesis, University of London.

Finch, B.\& Luebbe, R. (2004). Operations Management. Fort Worth, TX: The Dryden Press.

Hails, A. J. (1997). Wetlands, Biodiversity, and the Ramsar Convention: The Role of the Convention on Wetlands and Wise Use of Biodiversity. Switzerland: Gland: Ramsar Convention Bureau.

Hasan, S., Wang, X., Khoo, Y. B., \& Foliente, G. (2017). Accessibility and socio-economic development of human settlements. PloS one, 12(6), e 0179620.

Ichuloi, A. (2018). Phenomenology of Planet Earth Ontology: A Stride towards Environmental Integrity and Conservation. International Journal of Humanities Social Sciences and Education, 5 (1),1-14.

Ichuloi, A. (2019). African indigenous cultural ontology and environmental conservation and management in some Kenyan communities. International Journal of Humanities and Education Research, 1(1), 17-26. 
East African Journal of Environment and Natural Resources, Volume 4, Issue 1, 2021

Article DOI: https://doi.org/10.37284/eajenr.4.1.471

Johnson, L. R. (2016). Community-based qualitative research: Approaches for education and the social sciences. Sage Publications.

Jones, M. (1983). Papyrus: a new fuel for the third world. New Sci.;(United Kingdom), 99(1370).

Kumar, R. (2014). Research Methodology: A Stepby-step Guide for Beginners ( $4^{\text {th }}$ ed.). Thousand Oaks, CA: SAGE.

Lincoln, Y. S., \& Denzin, N. K. (Eds.). (2000). The handbook of qualitative research. London: Sage.

Matano, G. (2015). Wetlands (4 ${ }^{\text {th }}$ ed.). New York: John Willey\& Sons.

Millennium Ecosystem Assessment Board. (2005). Ecosystems and human well-being: current state and trends. Millennium Ecosystem Assessment Board.

Mugenda, M., \& Mugenda, G. (2003). Research Methods: Quantitative and Qualitative Approaches. Nairobi.

Nguyen, H. H., Dargusch, P., Moss, P., \& Aziz, A. A. (2017). Land-use change and socioecological drivers of wetland conversion in $\mathrm{Ha}$ Tien Plain, Mekong Delta, Vietnam. Land Use Policy, 64, 101-113.

Orodho, A. J. (2009). Elements of Education and Social Science; Research Methods ( $2^{\text {nd }}$ Edition). Masola Publishers.

Powell, B., Hall, J., \& Johns, T. (2011). Forest cover, use and dietary intake in the East Usambara Mountains, Tanzania. International Forestry Review, 13(3), 305-317.

Ramsar Convention Secretariat. (2010). Inventory, Assessment, and Monitoring: An Integrated Framework for Wetland Inventory, Assessment, and Monitoring. Ramsar handbooks for the wise use of wetlands, $4^{\text {th }}$ edition. Gland, Switzerland. Ramsar Convention.

Roy, D., Barr, J. \& Venema, D. H. (2011). Ecosystem Approaches in Integrated Water Resources Management (IWRM): A Review of Tran boundary River Basins. International Institute for Sustainable Development.
Sunderland, T., Achdiawan, R., Angelsen, A., Babigumira, R., Ickowitz, A., Paumgarten, F., ... \& Shively, G. (2014). Challenging perceptions about men, women, and forest product use: a global comparative study. World Development, 64, S56-S66.

38 This work is licensed under a Creative Commons Attribution 4.0 International License. 